\title{
30. DEEP-SEA OSTRACODA FROM DEEP SEA DRILLING PROJECT SITE 435, JAPAN TRENCH
}

\author{
Tetsuro Hanai, Geological Institute, The University of Tokyo, Tokyo, Japan \\ Noriyuki Ikeya, Shizuoka University, Shizuoka, Japan \\ and \\ Michiko Yajima, Geological Institute, The University of Tokyo, Tokyo, Japan
}

\section{INTRODUCTION}

Samples examined in this study were provided by DSDP from Leg 56, Japan Trench transect. The occurrence information on fossil ostracodes is outlined below:

Sample 435-1-2, 33-35 cm, Wichmannella sp. cf. $W$. circumdentata (Brady, 1880), a broken right valve; Krithe sp., a broken left valve. Sample 435-1-3, 33-35 $\mathrm{cm}$, Wichmannella sp. cf. W. circumdentata, two left valves. Sample 435-1-4, 33-35 cm, a broken valve, genus and species indeterminable. Sample 435-1, CC, 8-10 cm, Wichmannella sp. cf. W. circumdentata, a right valve, young instar.

Sample 435-4-1, 22-24 cm, a broken valve, genus and species indeterminable.

Sample 435-6-5, 30-32 cm, Krithe sp., a right valve.

The specimens apparently represent a mixture of nektonic and benthic forms. Krithe swims over the bottom, and Wichmannella perhaps crawls just below the sediment water interface. The genus Krithe, particularly large forms such as the present species, is very common in present-day oceans at bathyal depths, but it is also found on bottom as shallow as the continental shelves. Species of Wichmannella may be cosmospolitan in deep water. They were obtained from the Tuamotu Archipelago area, at a depth of 4700 feet (Puri and Hulings, 1976), and from the Mozambique Channel, Indian Ocean, at a depth of 3100 meters (Sylvester-Bradley and Benson, 1971). Pliocene specimens of the same species occurred approximately 6.5 meters below the top of a core from the Bauer Deep in the South Pacific (Wall and Quilty, 1976), where the water depth is 4296 meters. The present specimens were obtained from the uppermost part of the upper-Pleistocene Globorotalia truncatulinoides Zone at Site 435, off Miyako, Japan, where the depth of occurrence was 1.8 to 8 meters from the top of the core and the present water depth is $\mathbf{3 4 0 0}$ meters.

These ostracodes were routinely separated during shipboard preparation of foraminifer samples. The paucity of ostracode specimens is related to the small sample size. In deeper waters, particularly, ostracode density is normally less than that of foraminifers. Study of the foraminifer assemblage suggests the existence of a slump from shallower waters (P. R. Thompson, pers. comm.). Whether ostracodes described here belong to an allochthonous assemblage associated with the ben- thic foraminifers or are part of an autochthonous assemblage cannot be determined.

All specimens are deposited in the collection of the Micropaleontological Laboratory, Institute of Geosciences, Shizuoka University (IGSU), Japan.

\section{TAXONOMIC NOTE}

Family CYTHERIDEIDAE Sars, 1925

Subfamily KRITHINAE Mandelstam, 1958

Genus Krithe Brady, Crosskey, and Robertson, 1874

Krithe sp.

(Plate 1, Figures 1, 3)

Remarks: There has been considerable confusion concerning the identification of some species of the genus Krithe, which traces back to Brady in the Challenger report, where in a discussion of $K$. produc$t a$ he mentioned that the species "is either a cosmopolitan one, and very variable as to shape, or the figures given under its name . . . must belong to other undescribed species" (Brady, 1880, p. 114). This genus is easily distinguishable from related genera in having a characteristic lateral outline and posterior incision in dorsal view. However, the smooth outer surface does not permit easy delineation of many other characters usable for species identification. Thus, earlier paleontologists tried to rely on subtle differences in lateral and dorsal outlines for species identification, disregarding the detailed structure of the carapace, for example, the radial pore canals and the shape of the vestibule. More-careful observation in recent years has resulted in daia on the details of the marginal infold, but its range of variation within a species still is not well understood. Thus, confusion about species in this genus remains.

Deeper-water Krithe have been reported by Brady (1880, pp. 113-116): $K$. bartonensis from the South Pacific, $K$. producta from the Atlantic and the Pacific, and $K$. tumida from the South Atlantic. Tressler $(1941$, pp. 99,100$)$ reported $K$. bartonensis, $K$. gracilis, and $K$. tumida from North Atlantic deep-sea cores. LeRoy and Levinson $(1974$, p. 24) reported $K$. sp. aff. $K$. bartonensis from the deep-water Pleistocene of the northern Gulf of Mexico. Wall and Quilty (1976, pp. 737, 738) reported three unidentified species of the genus Krithe from the Pliocene, Miocene, and Oligocene of the Bauer Deep and Peru Basin. Among these deep-water Krithe, K. bartonensis of Tressler and Krithe sp. 1 of Wall and Quilty (1976, pl. 1, figs. 1-4) have a lateral outline most similar to the Site 435 specimens. However, $K$. bartonensis was originally described by Jones $(1857$, p. 50$)$ from the Bartonian Eocene of England. It is not likely that the Eocene and Quaternary forms are conspecific, but further study is needed before a final identification can be made.

Detailed observation of the right valve from Site 435 under the scanning electron microscope (SEM) clarified the nature of the normal pores, which have a sieve plate with a lipped pore in their center. However, these characteristics seem to be common to the genus Krithe and allied genera. In the classification of Puri (1974, pp. 137, 146), they are "Type C"' pores.

Occurrence: DSDP Site 435, Sample 435-1-2, 33-35 cm (IGSUO-3, a broken left valve); $435-6-5,30-32 \mathrm{~cm}$ (IGSU-O-1, a right valve, length $0.88 \mathrm{~mm}$, height $0.48 \mathrm{~mm}$ ). 
Family TRACHYLEBERIDIDAE Sylvester-Bradley, 1948 Subfamily ROCALEBERIDINAE Bertels, 1969 Genus Wichmannella Bertels, 1969

Wichmannella sp. cf. W. circumdentata (Brady, 1880) Plate 1, Figures 2, 4-8

Cythere circumdentata BRADY, 1880, p. 106, pl. 26, figs. 2a-c. Henryhowella sp. SYLVESTER-BRADLEY and BENSON, 1971, p. 267, figs. 20A-C.

Echinocythereis sp. WALL and QUILTY, 1976, pl. 1, fig. 12.

Remarks: Adductor-muscle scars of the present specimens are essentially of the trachyleberid type, i.e., four vertically arranged scars and one heart-shaped scar in front. Of the four adductor scars, the large, club-shaped dorsomedian scar is disposed obliquely towards the anteroventral area, inflated side downwards, and the dorsal adductor is inclined towards the anterodorsal area. This muscle-scar pattern is consistent with characteristics of Subfamily Rocaleberidinae. With one exception, other external and internal morphologic features of the Site $\mathbf{4 3 5}$ specimens suggest placement in Wichmannella, a Cretaceous to Holocene genus. The present specimens, however, have no eye tubercle or ocular sinus, which, as diagnosed by Bertels $(1969$, p. 164) is characteristic of Wichmannella. However, in some other eurybathic trachyleberid genera, such as Echinocythereis, the deep-water species are without eyes, whereas the shallow-water forms possess them (see Benson, 1975). Wichmannella also seems to fall in this category.

This species is probably Wichmannella circumdentata (Brady, 1880), of which the lectotype is from the Tuamotu Archipelago area, in $\mathbf{4 7 0 0}$ feet of water (Puri and Hulings, 1976). Identification cannot be conclusive without additional, comparative material.

Henryhowella sp. collected by the International Indian Ocean Expedition, 1963-1964, (Loc. IIOE 410A, Mozambique Channel) and illustrated by Sylvester-Bradley and Benson (1971, p. 267, figs. 20A-C) is closely similar to the present specimens in the arrangement of spines or nodes with a cluster of radiating small spines on their tips. A normal pore consists of a sunken sieve plate with a protruding central pore. They are confined to muri. The pan-like floors and wrinkled muri form a single mesh of reticulation. All these characteristics suggest that the Site 435 specimens and the Indian Ocean form are conspecific, in spite of the distance between the two localities.

Echinocythereis sp. from the Pliocene of the Bauer Deep in the South Pacific, illustrated by Wall and Quilty (1976, pl. 1, fig. 12), also seems to be conspecific with the Site 435 species, although their figure does not illustrate the details of the spines. The overall pattern of reticulation of the Bauer Deep specimen is closely similar to that of the present specimens.

Occurrence: DSDP Site 435, Sample 435-1-2, 33-35 cm (IGSUO-4, a broken right valve); 435-1-3, 33-35 cm (IGSU-O-2, a left valve, length $0.95 \mathrm{~mm}$, height $0.56 \mathrm{~mm}$; IGSU-O-5, a left valve, young instar, length $0.90 \mathrm{~mm}$, height $0.54 \mathrm{~mm}$ ); $435-1, \mathrm{CC}, 8-10 \mathrm{~cm}$ (IGSUO-6, a right valve, young instar, length $0.45 \mathrm{~mm}$, height $0.30 \mathrm{~mm}$ ).

\section{ACKNOWLEDGMENTS}

The authors express their appreciation to Drs. Joseph E. Hazel, Hakyu Okada, and Tsunemasa Saito for their reviews of this report, to Mr. P. R. Thompson for providing information on foraminifer assemblages, and to Miss Kazumi Nishii for preparation of the SEM photography.

\section{REFERENCES}

Benson, R. H., 1975. Morphologic stability in Ostracoda. Bull. Am. Paleont., 65 (282), 13-46.

Bertels, A., 1969. Rocaleberidinae, nueva subfamilia (Ostracoda, Crustacea) del limite Cretacico-Terciario de Patagonia septentrional (Argentina). Ameghiniana. Rev. Assoc. Paleont. Argentina, 6, 146-171.

Brady, G. S., 1880. Report on the Ostracoda dredged by $\mathrm{H}$. M. S. Challenger, during the years 1873-1876. Rept. Voy. Challenger, Zool., 1 (3), 1-184.

Jones, T. R., 1857. A Monograph of the Tertiary Entomostraca of England: London (Paleontographical Soc. London), pp. 1-68.

LeRoy, D. O., and Levinson, S. A., 1974. A deep-water Pleistocene microfossil assemblage from a well in the northern Gulf of Mexico. Micropaleont., 20, 1-37.

Puri, H. S., 1974. Normal pores and phylogeny of Ostracoda. In van den Bold, W. A. (Ed.), Ostracoda (Geoscience and Man, 6): Baton Rouge (La. St. Univ.), 137-157.

Puri, H. S., and Hulings, N. C., 1976. Designation of lectotypes of some ostracods from the Challenger Expedition. Bull. Brit. Museum (Nat. Hist.), Zool., 29 (5), 249-315.

Sylvester-Bradley, P. C., and Benson, R. H., 1971. Terminology for surface features in ornate ostracodes. Lethaia, 4, 249-286.

Tressler, M. L., 1941. Geology and biology of north Atlantic deep-sea cores between Newfoundland and Ireland. U.S. Geol. Surv. Prof. Paper, 196-C, 95-104.

Wall, D. R., and Quilty, P. G., 1976. Ostracodes-Leg 34. In Keats, R. S., Hart, S. R., et al., Init. Repts. DSDP, 34: Washington (U.S. Govt. Printing Office), 737-739.

\section{PLATE 1 \\ Ostracodes from DSDP Site 435.}

Figures 1, 3 Krithe sp. IGSU-O-1, Sample 435-6-5, 30-32 cm, a right valve. 1a, b, exterior lateral view, stereo pair, $\times 66.1 \mathrm{c}$, interior lateral view, $\times 66.3 \mathrm{a}, \mathrm{b}$, a normal pore in dorsocentral area of carapace, exterior view, stereo pair, $\times 2400$.

Figures 2, 4-8 Wichmannella sp. cf. W. circumdentata (Brady, 1880). IGSU-O-2, Sample $435-1-3,33-35 \mathrm{~cm}$, a left valve. $2 \mathrm{a}$, b, exterior lateral view, stereo pair, $\times 60$. $2 c$, interior lateral view, $\times 60.4$, a normal pore between frontal scar and adductor-muscle scars, interior view, $\times 1800.5 \mathrm{a}, \mathrm{b}$, a normal pore in anterodorsal area of carapace, exterior view, stereo pair, $\times 3240$. 6 , adductor-muscle scars and frontal scar, interior view, $\times 180.7 \mathrm{a}, \mathrm{b}$, spines on muri, just above muscle-scar area, exterior view, stereo pair, $\times 564$. 8 , a normal pore on murus in area just above adductor-muscle scars, exterior view, $\times 900$. 
PLATE 1
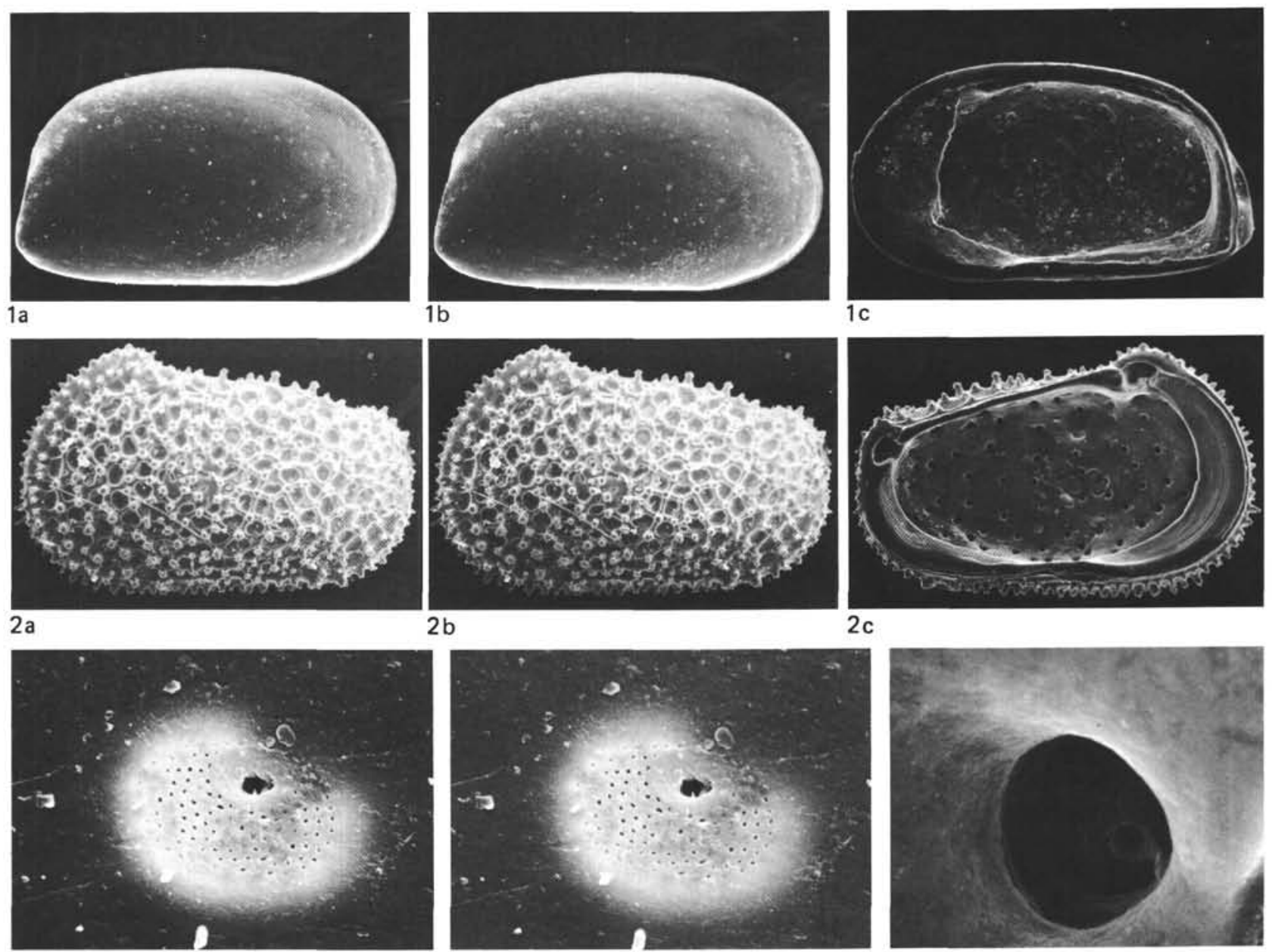

$2 b$

2c

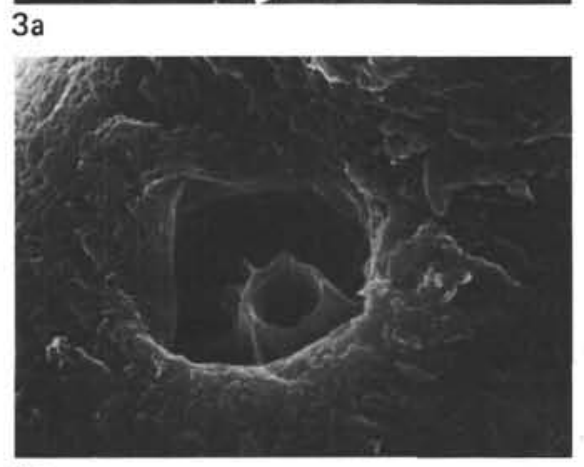

$5 a$

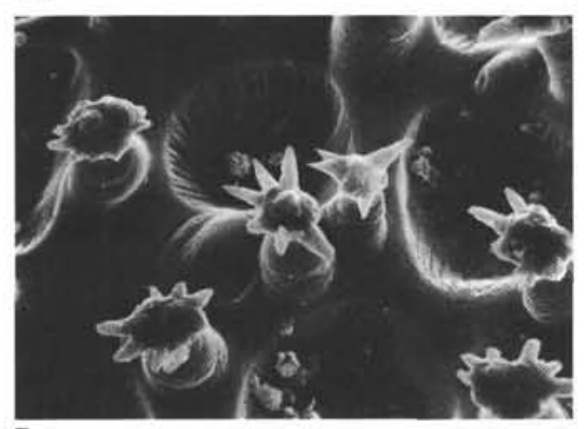

$7 a$

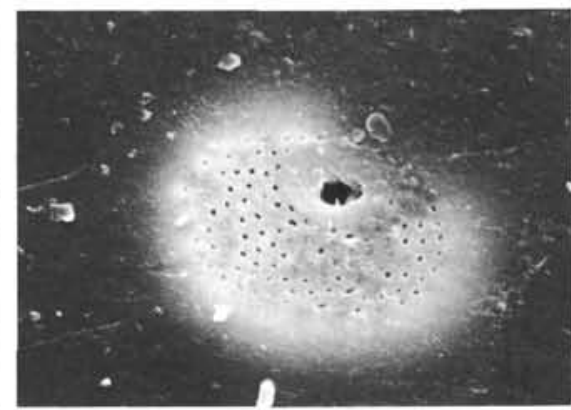

$3 b$

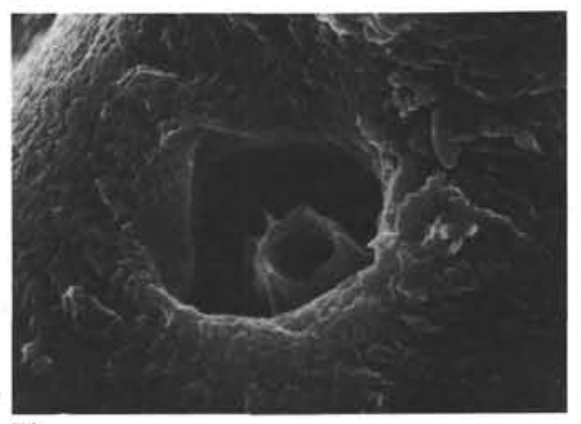

$5 b$

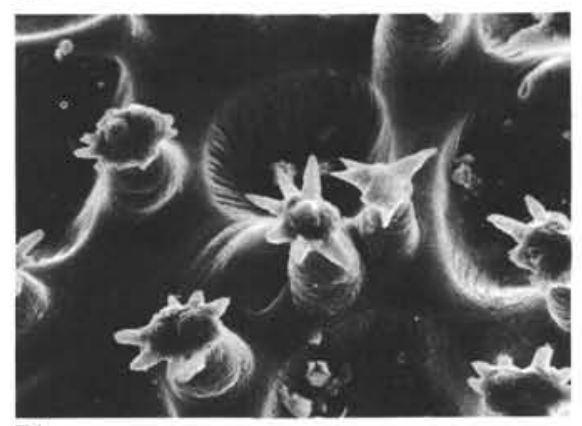

$7 b$

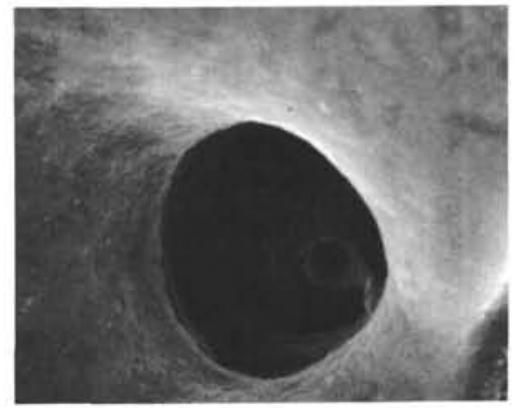

4

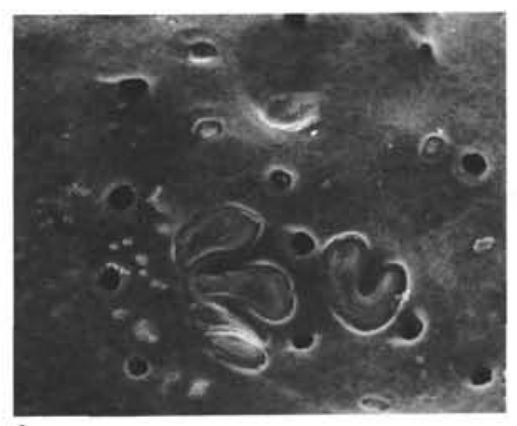

6

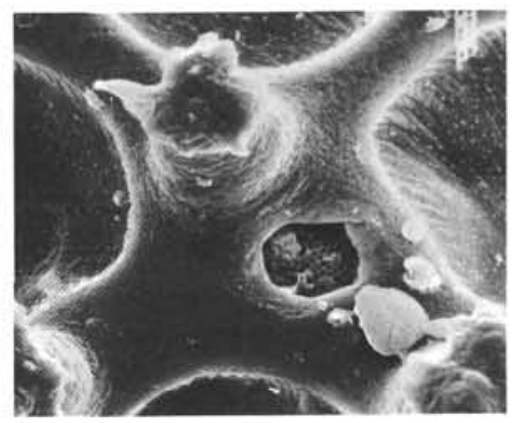

8 